\title{
Assessment of Enhancing Transparency of Financial Statements
}

\author{
Dr. Viswa Nadham N. \\ Lecturer, School of Business Studies, the University of Dodoma \\ Tanzania \\ Email: viswa_369@yahoo.com
}

Received: August 25, 2016 Accepted: September 28, 2016 Published: October 10, 2016

doi:10.5296/ijafr.v6i2.9946 URL: http://dx.doi.org/10.5296/ijafr.v6i2. 9946

\begin{abstract}
The study explored both the advantages of transparency and challenges facing finance departments of local government authorities in the course of preparing and presenting financial information.

The study employed an explanatory case study,cross-sectional survey and applied a triangulation of methods to collect both qualitative and quantitative data. The participants were all selected based on the opportunity to learn and the typicality of Dodoma municipality.A total of 80 respondents were involved. Data analysis was done through SPSS. Figures, tables, pattern matching, comparison and strong explanation building all aided in simplifying the analyses of findings.

Key findings of the study unveiled that participation of the public in finance affairs of local governments heightened transparency in the preparation and presentation of financial statements. Furthermore, the finding reveal that International Finnancial Report Standards (IFRS) was rarely applicable during the preparation of financial statement. It was also found out that tansparency in financial matters reduced fraudulent behaviours in the allocation and expenditure of local government funds.
\end{abstract}

Keywords: Financial statements, IFRS, IAS, Financial transperancy 


\section{Introduction}

Transparency in preparing and presenting financial statements reduces financial mismanagement. It was learned that if the public knows the sources of financing and how the municipality is using the funds, then they can easily follow and track the implementation of different projects and activities. With this knowledge, people can easily monitor the timely, efficient and effective accomplishment of different projectcs in their local government. On the other hand, the officers tasked with overseeing different projects and activities will act diligently when they learn they are monitored by the public.In the last decades, many public sector entities worldwide have been resorting to information and communication technologies for service improvement, innovation and participation processes, as a means to promote transparency and accountability - especially through more information disclosure - and responsiveness towards citizens and other stakeholders (Tweedle, 2005)The majority of companies that are currently reporting financial results based on IFRS have only been doing so for a few years. In order for IFRS to fulfill the promise it holds to be a uniting force of the world's capital markets and a powerful tool for investors everywhere, there are a handful of principles that are critical to its success. For various reasons one would like to know the position of the organisation concerning financial matters during a particular period of time, that's why there is a need for public and private institutions to produce good accounting financial statements (Yen, 2004).IMF (2000) ascertains that if financial statements could be prepared using one set of universally accepted accounting standards, then their understanding could be extended to users in different countries.

The quest to acquire such a set of standards is behind the International Financial Reporting Standards (IFRS) promulgated by the International Accounting Standards Board (IASB).Moreno and Singer (2005) in their study found that in most developing countries transparency on the preparation of the financial statement is questionable and sometimes being interfered by politicians. They further suggest that there is a necessity of public organization's to be very transparent at any time so that they can bring a true picture of such entity. However, in Tanzania, transparency is a recognized constitutional and statutory right under Article 132(5) sub section (f) of the Tanzania constitution (which declares transparency as a basic principle of ethics for public leadership), and Section 49 of the 1982 local government finances Act. In Tanzania, the financial reports are guided by the National Board of Accountants and auditors (NBAA) as professional accountancy body established under the accountants and auditors (Registration) Act No. 33 of 1972 as ended by the Act No. 1995 (Killagane, 2006).Many organizations in Tanzania face problems in preparation of financial statements, across the country there has arisen several complaints about the information provided in the prepared financial statements to end users (Bert, 2006).

It has been argued that in Tanzania efforts have been made on enactment of a new legal framework for fiscal management and procurement, enhanced controls on commitments and expenditure and quarterly publication of the amount and timing of budget transfers to spending agencies and local governments. Still, there are shortcomings in preparation of financial statements coupled by unpreventable financial statement (URT, 1999). These shortcomings in management of finance were to be checked if local governments are to fulfill 


\section{Mll Macrothink}

International Journal of Accounting and Financial Reporting

ISSN 2162-3082

2016, Vol. 6, No. 2

their purpose of establishment. A comprehensive study was thus needed to identify the role transparency could play in enhancing the quality and credibility of financial statements.

However, experience shows that the application of the accounting principles, concepts such as going concern, accrual basis, materiality and aggregation and consistency are distorted by personal views and biases of accounting system of an organization. These affect the truth and quality of the information presented (Bert, 2006).

\section{Literature Review}

According to IFRS (2010), Financial statements are defined as structured financial representation of the financial position and the transactions undertaken by an enterprise. Financial statements as a structured presentation of the financial position and finical performance of an entity. Financial statements are prepared information about the financial position, performance and cash flow of an entity that is useful to a wide range of the users in making decision (Killagane, 2000:215 -216)

According to Elliot (2006) stipulates that, in assessing and selecting staff for the financial statement team, it is important that the team collectively possesses the appropriate capabilities and knowledge to prepare the financial statements. These include an understanding of practical experience in preparing financial statements of a similar nature and complexity a sound understanding of accounting standards and practice, financial reporting and accountability, and legal and reporting requirements appropriate technical knowledge, including knowledge of relevant systems.

Developing countries also have a remarkable experience on transparency of financial statements. Good examples may be drawn from Asian countries that have examined transparency across 434 Firms from 12 Countries and tested country level variability in explaining variation in financial transparency (tweedle, 2005) Transparency was measured using checklist of 228 and 441 items from IFRSs in 2002.In the case of India transparency gained a lot of momentum in the corporations that have no choice but to make their operations transparent and be open to their stakeholders and also to the entire community.

The main objective of financial statement is to communicate economic measurements of information about resourses and performance of the reporting entity useful to those having reasonable rights to such information (Collier,2012)

Kilagane (2006) associated the budget with transparency by ascertaining that, improving the budget framework one of the key elements in enforcing accountability through the implementation of the budget. Transparency in administration is a topic recurrently studied, especially in international finance contexts (Kulzik, 2004).

Democratic accountability requires governments to increase transparency by disclosing more budgetary and financial information to citizens, hence promoting public expenditure scrutiny and preventing corruption and wasting of public resources (Kenneth, 2005).

According to Elliot (2006) stipulates that, in assessing and selecting staff for the financial statement team, it is important that the team collectively possesses the appropriate 


\section{Macrothink \\ International Journal of Accounting and Financial Reporting

capabilities and knowledge to prepare the financial statements.

\section{Methodology}

\subsection{Location}

According to Kothari (2004) convenience is enough justification to select an area for study as well as subjects to be included in the study.Dodoma Municipality is relatively located at the centre of the country.The study was carried out in Dodoma Municipal Council.

\subsection{Sample Size}

The sample size is a small part selected from a larger whole in which the researcher is interesting in gaining information and drawing conclusion (Babbie, 1992). In estimating sample size, the following formula was used:

$\mathrm{n}=\left(\mathrm{Z}_{\alpha} \underline{\Omega} / 2\right)^{2} \mathrm{P}(1-\mathrm{P}) \lambda^{2}$

Whereby; $\mathrm{n}=$ sample size, $\mathrm{P}=$ Percentage of local government workers involving in financial department and $\lambda=$ Maximum error: since $\mathrm{P}$ is not known for the study population, its value is assumed to be $50 \%$ as it ensures maximum sample size (Amin, 2005). By using a confidence interval of $95 \%$ for the estimated population proportion, maximum error of $10 \%$ and a nonresponse rate of 5\%, a final sample size involved in a study were 80 local government workers in ward and street level and other $10 \mathrm{key}$ informants from the municipal finance department to make total of 90 respondents.

\subsection{Sampling Technique}

There are mainly two sampling techniques which are probability and non probability techniques (Kothari, 2004). The particular technique that was used in this study was simple random probability sampling which was based on the rule that every element in population had an equal chance of being sampled.This technique of simple random probability sampling is basic and least complicated technique since the sampling is without replacement, it assumes that the population is known and it requeres a complete list of all elements and assumes that such elements are statistically independent of one another (Kothari,2004).

\subsection{Data Collection Methods}

Both primary and secondary data were collected. Primary data was collected through questionnaires and interviews, and also secondary data were obtained from literature sources or data collected by other people's findings.

\subsection{Data Analysis}

Mngarah (2008) defines data analysis as a process of systematically searching through and arranging the interviews, transcripts, field notes and other materials that a researcher accumulated to increase his or her understanding of them, and to enable the researcher to present what he discovered to others. Data analysis was done using both the Statistical Package for Social Sciences (SPSS) and Microsoft Excel. 


\section{Macrothink \\ International Journal of Accounting and Financial Reporting \\ ISSN 2162-3082 2016, Vol. 6, No. 2}

\section{Discussion}

\subsection{Distribution of the Respondents by their Working Experience}

As regards personal information, participants were last asked to state their working experience in years. Table one summarizes the results.

Table one: Distribution of the Respondents by their Working Experience

Working Experience Frequency Percent

- Less than 5 Years

19

35

- $05-10$ Years

- $\quad 11-15$ Years

10

- $16-20$ Years

8

- Above 20 Years

Total

\section{5}

45

12.5

10

10

100

Source: Field Work survey, 2015

In table one illustrates the distribution of the respondents according to their working experience. It was observed that $18(22.5 \%)$ of respondents had worked for less than five years. $36(45 \%)$ of the respondents had $5-10$ years of working experience, and $16-20$ and 21 and above years of working experience had $8(10 \%)$ each among the participants.

\subsection{The Contribution of Participation in Enhancing Transparency of Financial Information in $L G A s$}

The interest in this information was to assess whether there are systems, regulations and guidelines in LGAs serious enough to ensure transparency prevails in the preparation and ultimate reporting of financial information. The transparency component was considered prominent and prerequisite to successful preparation and reporting of financial information. multiple questions were administered to both street or village and ward participants on one hand, and the ten municipal officers in the finance department, on the other. The questions for the first group of village or street and ward officers were to assess whether and to what extent they were involved or consulted by the municipal authorities in preparing and reporting of financial information. It should be noted that street and ward officers in different positions are the very primary representatives of the public. Moreover, their decisions are usually made through direct participation of local citizens. Their involvement thus, can be interpreted as a direct involvement of the general public in the financial affairs of the municipality. Such involvement and participation enhances transparency. Participants thus, were first inquired 


\section{Macrothink \\ International Journal of Accounting and Financial Reporting \\ ISSN 2162-3082 \\ 2016, Vol. 6, No. 2}

whether or not they were being involved in the preparation of financial statements for the municipality. The findings summarised in figure one below.

Figure : 1Involvement in preparing Financial Statements

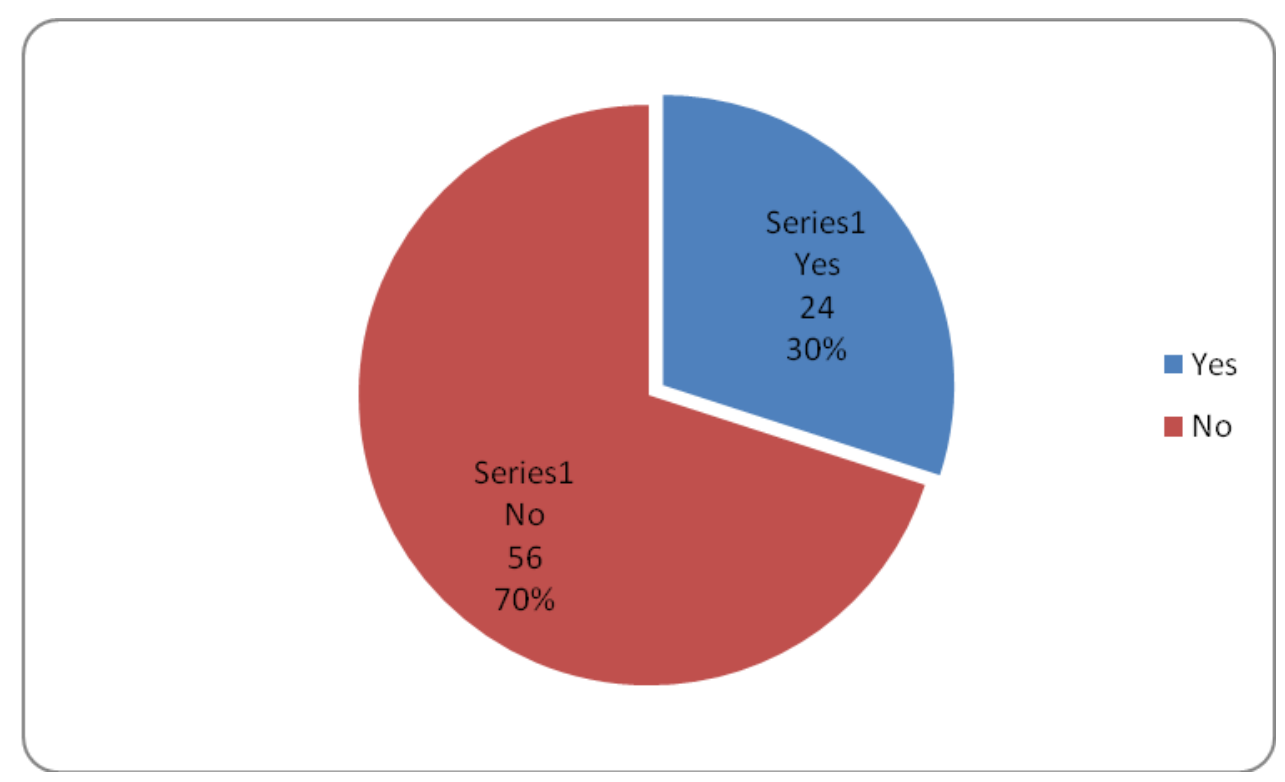

Source: Field Study, 2015

The pie chart above illustrates that only 24(30\%) participants in the local level, accepted that they were being involved in preparing financial statements of the municipality. The vast majority $56(70 \%)$ participants declined that they were not being involved in the preparation of municipal financial statements.

Table Two: Modes of involved in the preparation of FS

\begin{tabular}{|c|c|c|c|c|}
\hline Modes & Frequency & $\begin{array}{l}\text { Overall } \\
\text { Percent }\end{array}$ & $\begin{array}{l}\text { Individal } \\
\text { case }(\%)\end{array}$ & Ranks \\
\hline $\begin{array}{l}\text { Through planning activities and } \\
\text { projects to be undertaken by the } \\
\text { municipality }\end{array}$ & 15 & 34 & 62.5 & 1 \\
\hline Through budget preparation & 12 & 27 & 50 & 2 \\
\hline Through meetings & 7 & 16 & 29 & 4 \\
\hline $\begin{array}{l}\text { Through announcements on notice } \\
\text { boards }\end{array}$ & 6 & 14 & 25 & 5 \\
\hline Through letters & 4 & 9 & 37.5 & 3 \\
\hline
\end{tabular}


As it is illustrated in table two above, many 15(62.5\%) respondents who accepted that they were being involved by the municipality identified planning of activities and projects as the most common mode of participation. It was learned that before budgeting, some street/village and ward officers would be summoned to discuss and identify priority areas and projects the municipal council would undertake in a financial year. Some respondents, however, remarked that many times the implemented projects and activities would have nothing in common to the ones agreed.

In addition to activity and project planning, it was observed that some street and ward officers were involved in budgeting. They would be summoned by the municipality in meetings to estimate municipal annual income and expenditure. By discussion some respondents added that sometimes they were asked to prepare budgets for their areas, particularly wards, then the aggregation of all wards form the municipal budget.

Other modes of involvement were identified as participation through meetings, announcements on notice boards and through letters. The latter two, however, appear more informative than participatory modes in preparing and ultimate reporting of financial statements.

It is generally learned that the very local grassroot level officers who primarily represent masses do not feel adequately involved in the financial affairs, particularly the preparation and reporting of municipal financial information. If leaders hold too many reservations on the transparency of the municipality, then it is no wonder that the public do not even know what is happening in their municipal council.

On the other hand, the ten key informants were first asked questions to assess whether and the extent the vouching exercise was transparent in the municipality. This was to establish the authenticity of the transactions presented and reported in financial reports. Table three summarises the findings using the likert scale weighting.

Table Three : extent of the vouching exercise

\begin{tabular}{llllll}
\hline Scale & Frequency & $\%$ & Weight & $\begin{array}{l}\text { Total } \\
\text { weight }\end{array}$ & $\begin{array}{l}\text { Average } \\
\text { weight }\end{array}$ \\
\hline Strongly agree & 5 & 50 & 4 & 20 & 4 \\
Agree & 2 & 20 & 3 & 6 & 3 \\
Disagree & 1 & 10 & 2 & 2 & 2 \\
\hline
\end{tabular}


Strongly

2

1

2

1

disagree

Total

10

100

10

30

10

Source: Field survey, 2015

Table three above depicts the analysis of the extent financial auditing is transparent in Dodoma municipality. It was observed that 5 officers in the municipal finance office observed that the exercise was very transparent. Some other two also accepted the exercise was transparent. In contrast, three respondents declined that the verification of accounting books was not transparent.using the likert scale the common opinion of all the respondents was agree that vouching exercise was transparent. One participant remarked it was hardly possible for the financial information to correctly reach the public when some officers in the municipal finance department did not have access to audited reports. The respondent added, some primary accounting books in his office had not been requested for verification for years despite the auditing exercise being done annually.

In another approach to gauge the transparency of financial information to the public, respondents in this category were asked whether they adhered to the accepted guidelines in reporting financial information. Particularly, they were asked whether the municipality abode by the International Financial Reporting Standards (IFRS) guidelines issued and constantly updated after 2001 by the International Accounting Standards Board (IASB). The standards were referred to as they are today used as a benchmark to assess transparency of financial information across the globe. This is contrasted to the effectiveness of local guidelines that some people think are dictated by political pressures. The following table presents a summary of the findings.

Table Four: Adherence to IFRS by the MC

\begin{tabular}{lll}
\hline & Frequency & Percent \\
\hline Yes & 4 & 40.0 \\
No & 6 & 60.0 \\
Total & 10 & 100.0 \\
\hline
\end{tabular}

Source: Field Study, 2015

It was observed from table four above that $6(60 \%)$ of the respondents in the municipal finance office declined that they did not abide by the International Financial Reporting Standards in their preparation and ultimate reporting of financial information. On the other hand, $4(40 \%)$ of the respondents confirm the remarks made earlier by one of the 
respondents that auditing (vouching) was done even without the inspection of primary documentary evidence such as invoices. In effect, this raises concerns whether financial information of the Dodoma municipality is transparent.

\subsection{Advantages of Transparency}

This study wished to establish whether local governments and their people can benefit from transparency in financial matters, particularly, preparation and presentation of financial statements. For that purpose, the study wished to identify the general advantages accruing from transparency in local governments. Given the nature of the question, multiple answers were given. So, respondents could identify as many advantages as they knew. As a result, responses may tally to a figure greater than the number of respondents. Table five below summarises the findings.

Table five: Advantages of Transparency

\begin{tabular}{|l|l|l|l|l|}
\hline Advantages & Frequency & $\begin{array}{l}\text { Overall } \\
\text { Percent }\end{array}$ & $\begin{array}{l}\text { Individual } \\
\text { case (\%) }\end{array}$ & Ranks \\
\hline $\begin{array}{l}\text { Reduction of financial } \\
\text { mismanagement }\end{array}$ & 62 & 32 & 77.5 & 1 \\
\hline $\begin{array}{l}\text { Increase of ward and pubic } \\
\text { participation }\end{array}$ & 43 & 23 & 53.8 & 2 \\
\hline $\begin{array}{l}\text { Local government officers } \\
\text { become more accountable } \\
\text { to their people }\end{array}$ & 39 & 20 & 48.8 & 3 \\
\hline $\begin{array}{l}\text { Transparency promotes } \\
\text { better and informed policy } \\
\text { decisions }\end{array}$ & 30 & 16 & 37.5 & 4 \\
\hline $\begin{array}{l}\text { Improved access to sources } \\
\text { of finance }\end{array}$ & 7 & 4 & 8.8 & 5 \\
\hline $\begin{array}{l}\text { It encourages other people } \\
\text { to contribute more and to } \\
\text { work hard }\end{array}$ & 4 & 2 & 5 & 6 \\
\hline $\begin{array}{l}\text { Transparency encourages } \\
\text { trustfulness of both leaders } \\
\text { and other stake holders to } \\
\text { their government }\end{array}$ & 4 & 5 & 6 & \\
\hline
\end{tabular}




\begin{tabular}{|l|l|l|l|l|}
\hline $\begin{array}{l}\text { It helps to encourage WEOs } \\
\text { to do well their work }\end{array}$ & 2 & 1 & 2.5 & 8 \\
\hline Total & 191 & 100 & 238.9 & \\
\hline
\end{tabular}

Source: Field study, 2015

By using multiple response analysis, it was found out that the overall percentages were $62(32 \%)$ for reduction of financial missmanagement, $43(23 \%)$ for increase of ward and public participation, 39(20\%) for local Government officers become more accountable to their peolple and 30(16\%) for transparency promote better and inform policy decisions. The percentage indicated that all the advantages were perceived to be accepted whereby reduction of financial missmanagement, increase of ward and public participation and local government officers become more accountable to their people ranked high. The individual case percentages were $62(77.5 \%)$ for reduction of financial mismanagement, $43(53.8 \%)$ for increase of ward and public participation, 39(48.8\%) for local Government officers become more accountable to their peolple. It was observed that these percentages $77.5 \%, 53.8 \%$ and $48.8 \%$ were higher than overall percentages, implying that the respondents highly valued the advantages especially the first, second and third.

\subsection{Reduction of Financial Mismanagement}

Transparency makes people know the revenue and expenditure of their councils. This makes them easily query expenditures that violate financial regulations. Moreover, people can relate the worth of projects and activities with set out budgets for their implementation. It is also possible to compare expenditures and project progress. Such transparency reduces questions and limits loopholes for both misallocation and misappropriation of public funds. Many $62(77.5 \%)$ of respondents, for instance, observed that tracking the progress of many projects was difficult because they did not know how much money was allocated to them and how many phases they would take before completion. It was thus difficult to understand even the correctness of their municipal financial statements.

\subsection{Increasing Public Participation}

Many 43(53.8\%) respondents also observed that transparency in financial affairs of the municipality enhances participation of the public. It was identified that when people know what is happening, their ambition to partricipate increases. Similarly, they become confident in their leaders. As a result of the these, people become ready to contribute both financially and materially to the development of their municipality. 


\section{Macrothink \\ International Journal of Accounting and Financial Reporting \\ ISSN 2162-3082 2016, Vol. 6, No. 2}

Table six: Challenges Facing the Finance Department in LGAs

\begin{tabular}{|l|l|l|l|l|}
\hline Challenges & Frequency & $\begin{array}{l}\text { Overall } \\
(\%)\end{array}$ & $\begin{array}{l}\text { Individual } \\
\text { case (\%) }\end{array}$ & Ranks \\
\hline $\begin{array}{l}\text { Limited access to development } \\
\text { finance }\end{array}$ & 58 & 16 & 73 & 1 \\
\hline $\begin{array}{l}\text { Political influence and pressures } \\
\text { Lack of experts }\end{array}$ & 53 & 14 & 66 & 2 \\
\hline $\begin{array}{l}\text { Little knowledge on accounting } \\
\text { and finance principles like IFRS }\end{array}$ & 45 & 12 & 58 & 3 \\
\hline $\begin{array}{l}\text { Conflicts of interest with CDA } \\
\text { Lack of transparency and } \\
\text { accountability on revenue } \\
\text { collection and expenditure }\end{array}$ & 34 & 12 & 56 & 4 \\
\hline $\begin{array}{l}\text { Corruption from } \\
\text { EPICOR to IPSAS }\end{array}$ & 25 & 11 & 55 & 5 \\
\hline $\begin{array}{l}\text { Delay of funds } \\
\text { Total }\end{array}$ & 370 & 10 & 49 & 76 \\
\hline
\end{tabular}

Source: Field study, 2015

By using Multiple Respose Analysis, it was observed that overall percentages were 58(16\%) for limited access to development finance, 53(14\%) for political influence and pressures and $46(12.4 \%)$ for lack of experts. The percentage indicated that all the challenges were perceived to face finance department in the preparation and presentation of financial statements whereby limited access to development finance, political influence and pressures and little knowledge on accounting and financial principals like IFRS ranked high. The individual case percentages were $58(73 \%)$ for limited access to development finance, 53(66\%) for political influence and pressures and 46(58\%) for lack of experts. It was observed that these percentages $73 \%, 66 \%$ and $58 \%$ were higher than overall percentages, implying that the respondents highly gave priority especially the first, second and third. 


\section{MlMacrothink}

International Journal of Accounting and Financial Reporting

ISSN 2162-3082

2016, Vol. 6, No. 2

\section{Conclusion}

Transparency enhances good allocation of resources, project time management, effective use of resources and public participation. It was also observed that transparency increases accountability and promote better policy decisions. Additionally, transparency act as a way foward for a municipal or a Government to qualify for an aid, loan from International monentary organizations or Development partiners.

While transparency remains of chief importance in managing local government funds, there remain many challenges that have made local government financial reporting intransparent. Among the challenges facing finance departments in local governments are the dictation of key financial decisions by politics, corruption, lack of expert skills in financial management and shortage of funds.

\section{References}

Aczel, A. D. (1999). Complete Business Statistics4 ${ }^{\text {th }}$ Edition, Irwin / Mc Grawn Hill international Edition Singapore

Amin, M.E. (2005). Foundation of Statistical Inference for Social Science Research, University of Makerere, Kampala, Uganda, 338pp.

Bert et al, (2006).TheQuest for Transparency in financial Report, In Dayton Beach. Business Research,Vol. 28, No.3, pp. 209-224.Buckingham, Open University Press.

Choi, D. and Meela, K (2007). International Accounting, Prentice Hall 2007 CR.

Chow, C and Wong, B. (1987). "Voluntary financial disclosures by Mexican Corporations", The Accounting Review, Vol. 62, pp. 533-41.

Collier,P.M (2012), Accounting for managers, Interpretation Accounting information for decision making 4th Edtion, Aston business school, UK.

Cooke, T. E. (1992). "The Impact of Size, Stock Market Listing and Industry Type on the Disclosure in the Annual Reports of Japanese Listed Corporations", Accounting and Business Research, Vol. 22, Summer, pp. 229-237.

DeAngelo L E (1981), "Auditor Size and Audit Quality", Journal of Accounting and Economics, Vol.3, pp. 183-199.

Denscombe, M.(2000).The Good Research Guide for small scale Social Research Projects.

Donna, L. S; Sidney, J. G; and Bryant ,S.M. (1999), "Acceptance and Observance of lASs: An Empirical Study of the Companies Claiming to Comply with lASs", International Journalof Accounting, Vol. 34, NO.1, pp. 11-48.

Dumontier. P. and Raffournier. B. (1998). "Why firms comply voluntarily with IAS: AnEmpirical Analysis with Swiss Data", Journal of International Financial Management and Accounting, Vol.9, No.3, pp. 216-245. 


\section{I Macrothink}

International Journal of Accounting and Financial Reporting

ISSN 2162-3082

2016, Vol. 6, No. 2

Elliot, J.(2006).Financial Accounting, Reporting and Analysis, International Edition, ( 2nd edition) Prentice Hall, New York.

Frank wood et al, (2005). Business Accounting one, $10^{\text {th }}$ Edition, Vol.1 \& 2, person Education

Gujarati. D. M. (2003). Basic Econometrics, 4th Edition, Mcgraw-Hill.

Hague, P; Hgue, N; and Morgan C. (2004). Market Research in Practice, Kongan press Ltd, Ghana IFTS around the world (202) available from http://www.iasb.org. retrieval on 14the may 2012

Irwin, Timothy,( 2012). Accounting Devices and Fiscal Illusions, IMF Staff Discussion Note 12/02 (Washington: International Monetary Fund).

IMF(2000).Local government finance reform. A system for the financing of local government.Geneva, switzland.

Inchausti, B. G. (1997). "The Influence of Company Characteristics and Accounting Regulations on Information Disclosed by Spanish Firms", European Accounting Review, Vol. 6, NO.1, pp. 45-68, International Monetary FundIMF Working Pape.

James S,(2001). LocalGovernment Financial transparency in Portugal and Italy a comparative exploratory study on its determinants. Coimbra Porttugal

Joshi. P. L. and Mudhahki .J. A. (2001). "Empirical Study of Compliance with International Financial Accountingfor professional student Vol2

Keneeth S, (2005).Transparency in Central Bank Financial Statement Disclosures. In E.S. Building an infrastructure for financial stability

Killagane S.M , (2011). Accounting Standards (IAS-1) by Sock Exchange Listed Companies in Bahrain", Journal of Financial Management and Analysis, Vol. 14, NO.2, pp. 43-54

Kolhari, P. (2000). "The role of financial reporting in reducing financial risks in the Market"

Kothari, (2004). Techniques Research methodology, methods, $2^{\text {nd }}$ Edition, New age international Publishers

Kulzik at el, (2004).Effects on financial transparency, SAM Advanced Management Juornal Publisher, Vol.69

Leung ,Q. W; Morris, R. D. and Gray, S. J. (2005), "Corporate Transparency in Ch ina: Factors Influencing Fi nancial Disclosu re Levels"

Matthew S,(2005).Local Parties and Local polies: Electoral Frementation and Municipal Budget Choices in Bolvia.Working paper:Duke University.

Moreno et al., (2005).Analyzing the Performance of Local Governments in Mexico:A Political Explanation of Municipal Budgetary Choices.

Ngalewa, E. (2003). Local Government Finances and Finacial Magement in Tanzania. Dar es 


\section{Macrothink \\ International Journal of Accounting and Financial Reporting \\ ISSN 2162-3082 \\ 2016, Vol. 6, No. 2}

Salaam.

National Audit Office(2006), Statutory Report Of the controller And Auditor General on the Financial Statements of local Government Authorities for the financial year ends 30th June 2005, Dar es salaam, The National Audit officer, 31st March 2006.

Oke, T. E. (1998). "Regression "Analy Co sis in Accounting Disclosure Studies", AccountingandFederal Reserve Bank of Boston Conference Series

Olowu D,(2006).Local institutional and Political structure and processes:recent experience in $\quad$ Africa, Public Administration Dev.23,41-52

Yin Robert K.(1994), Case study Research design and methods, New bury parks, CA:Sage publication 1994.

Shields et al., (2006). Intermediate Theory:The missing link in successful student scholarship.Juornal of Public affairs Education. Vol12, No.3.Pg313-334

Sunder,S. (2003).Theory of Accounting and Control. Cincinnati, Ohio,South-Western, Publishing.

Suresh, S. and Tony B.(2004).Transparency and Accountsbility in Public Financial .Administration. Arab Region

Tweedle, E.J.(2005). Business Finance for Decision makers, London: Pitman Publisher

URT (2011).The National Ant-corruption Strategy and Action plan for Tanzania. Dar es Salaam:The President's Office.

URT (2006). Local Goverment Fiscal Review, Dar es Salaam.

United States, Congressional Budget Office (CBO) (2009). The Budget and Economic Outlook: An Update. Washington

Varadraj et al., (2008).Corporate Transparency through implementaion of Indian Accounting standards,Mumbai

Yen, B.(2004). Asian Juornal of Finance and Accounting Vol 3,No 1:E1 Publishers.

Yona V.K. (2006). Management Accounting: An Introduction, Student Edition( Hard cover), Financial Times Prientice Hall

William, J.T(1993), Accounting principles, New york, McGraw-Hill.

National Bank of Romania (2011), Audit Report and the Transparency of Credit Institutions from Romania

Stephen Yan (2004), Determinants of Corporate Disclosure and Transparency

Varadraj Bapat (1998), Corporate Transparency through Implementation of Indian Accounting standards. 


\section{Macrothink \\ International Journal of Accounting and Financial Reporting \\ ISSN 2162-3082}

\section{Copyright Disclaimer}

Copyright for this article is retained by the author(s), with first publication rights granted to the journal.

This is an open-access article distributed under the terms and conditions of the Creative Commons Attribution license (http://creativecommons.org/licenses/by/3.0/). 